\title{
SEMANTIC FEATURES OF DIMINUTIVES AND AUGMENTATIVES IN MODERN SPANISH
}

\author{
Stepanov A. V.
}

\section{INTRODUCTION}

Problems of the theory of the meaning of the word taking into account the regional variability of the Spanish language and the realization of the meaning of the word in its national variants (the term introduced by G.V. Stepanov ${ }^{1}$ ) are attracting the attention of many scholars. Diminutive and augmentative derivative formations are of particular interest, as well as their structure, meanings, and functioning. Diminutives and augmentatives are an indispensable characteristic feature of the Spanish language and its national variants, as evidenced by the relatively large number of derivative morphemes for their formation and the high fluidity in language and speech, which causes new pragmatic and stylistic intentions of their use, variability of meanings, proneness to semantic changes and further development of form and meaning.

Diminutives and augmentatives usually possess a complex semantic structure, which is manifested in their polysemy, variability of denotative and connotative meanings and their pragmatic characteristics. Frequent stylistic colouring and contextualization of the use of these derivatives contributes to the development of new meanings of diminutive and augmentative formations, their lexicalization and terminologization. In the processes of development of the lexical and semantic system of a language in general, and in the term formation in particular, the semantic derivation (the term introduced by D.M. Shmelev ${ }^{2}$ ) plays an important role since it consists in the formation within words of new meanings, the so-called "meaning transitions" and "meaning transfers" that lead to the development of polysemy.

In Hispanic studies, much attention has been focused on the study of Latin American national variants of Spanish, however, semantic derivation as a means of enlarging and enriching vocabulary has been described either fragmentarily, within broader research topics, or without sufficient attention

\footnotetext{
${ }^{1}$ Степанов Г.В. Социально-географическая дифференциация испанского языка Америки на уровне национальных вариантов. Вопросы социальной лингвистики. Ленинград, 1969. С. 302-305.

${ }^{2}$ Шмелев Д.Н. Проблемы семантического анализа лексики. Москва, 1973.
} 
to diminutive and augmentative formations (J. Rivarola, A. Rosenblat, J. Lope Blanch, A. Garrido Domínguez, G. de Granda, G.V. Stepanov, N.M. Alesina, and others). A number of scholars specializing in Hispanic linguistics (E. Náñez-Fernández, M. Dolores Muñoz, A. Alonso, A. D'Angelis, J. Dávila, J. Montes Giraldo, etc.) have been studying diminutives and augmentatives in terms of their morphological, morphonological, stylistic, and pragmatic aspects, while their semantic features have been researched to a lesser extent. In addition, the conducted studies were largely based on the Iberian national variant Spanish. The exceptions are the works of Charles Kaney and Jeanette Reynoso Noverón. Ch. Kaney is the first linguist to publish a fundamental research on American Spanish Semantics ${ }^{3}$, nevertheless his work focuses on Latin American semantics as a whole but does not consider the semantics of diminutives and augmentatives in particular or the terminological processes of these derivatives.

Thus, the problems of semantics of diminutives and augmentatives and the processes of semantic derivation in Spanish, including the Latin American national variants of the language, have not been sufficiently covered in modern linguistic science. The lack of attention to this method of updating the lexical and semantic system and terminology can be explained, first of all, by the lack of exploration, which would summarize the achievements in comprehending lexical and semantic derivation as a special dynamic phenomenon combining synchronicity of the language with its diachronic state and reflecting the linguistic world view of the Spanish speaking people. In addition, from the point of view of onomasiology, the process of semantic derivation is the use of a well-known word (its outer form) for the nomination of a new object, that is, a secondary nomination (term coined by V.M. Telia ${ }^{4}$ ). There are no studies based on Spanish diminutives and augmentatives, which take into account the dual nature of semantic derivation and its simultaneous entry into the paradigm of semasiology and onomasiology.

When investigating the semantic derivation of diminutives and augmentatives as a particular phenomenon of national variants of the Spanish language, in our opinion, we must take a dual approach in terms of semantics and word formation, since we believe that when it comes to diminutive and augmentative suffixes, semantic derivatives is in close connection and even dependent on morphological derivation. In the same

3 Kany Ch.E. American Spanish Semantics. The University of California Press, 1960. 295 p.; Kany Ch.E. Semántica hispanoamericana. Madrid : Aguilar, 1962. 298 p.

4 Телия В.Н. Вторичная номинация и ее виды. Языковая номинация. Виды наименований. Москва : Наука, 1977. С. 129-221. 
way, we consider the notion of term formation as one of the most important manifestations of semantic derivation of diminutives and augmentatives since the common vocabulary is an important source of development and replenishment of the term system, and the constituents within the opposition "common word" - "term" are in organic connection.

\section{Types of semantic changes}

The development of language is accompanied by constant changes. Any language changes occur under their own laws, which are objective in nature, and are predetermined by extra and intralingual factors. In this case, the lexical and semantic system of language changes most rapidly, compared to its phonetic, phonological and grammatical systems. The common cause of any language change is the principle of language functionality, that is, the effective implementation by the language of its main functions: communicative, nominative, expressive, etc. In the lexical and semantic system of language, researchers identify four types of change: 1) extinction of words; 2) extinction of meanings of words; 3 ) emergence of new words; 4) emergence of new meanings. In the context of studying semantic derivation, semantic changes related to the sphere of change of the word's meaning are of high interest, but we are to keep in mind that the implementation of semantic changes is associated with lexical changes and there is a causal relationship between the two phenomena.

There are several classifications for the causes of semantic change that underlie different principles and criteria as a basis for grouping. K. Baldinger distinguishes five types of causes of semantic change: linguistic (contextual influence), cultural and historical, social (the transition of a word from one social sphere to another), mental (linguistic taboo, euphemisms) and psychological $^{5}$. G. Kronasser identifies the primary and secondary causes of semantic modifications. The researcher attributes the influence of environmental reality, mental and physiological causes to the primary ones. Secondary causes are linguistic: the shift of synonyms in semantic fields, "contagion in con-associations", which is the divergence between the limited number of words and the boundlessness of phenomena ${ }^{5}$. Thus, G. Kronasser rightly noted the unevenness of external and internal factors of semantic changes and identified the links between individual factors.

Therefore, based on the above, we can propose the following classification of causes of language changes:

1. Extrinsic (Extra-lingual) causes. These are caused by the needs of communication in a broad sense, that is, the needs of expression and transmission by the speakers of their own thoughts and feelings.

\footnotetext{
${ }^{5}$ Левицкий В. Семасиология. Винница : Нова книга, 2012. С. 312-313.
} 
The development of human cognitive activity requires the need to name and formulate with linguistic means those concepts and phenomena that become the subject of human activity. Changes in the development of society, scientific and technological progress contribute to the emergence of new objects. These objects of environmental reality are new concepts that need a name and characteristics. That is, the occurrence, alteration, extinction or disappearance of objects, phenomena, actions, etc. are reflected in the lexical and semantic system of language and cause language changes at this level. The changes of this type result in: 1) the emergence of a new lexeme (lexical item or lexical token). Such an emergence may occur through word formation, neology or borrowing. The changes of this kind occur at the lexical and semantic level of language; 2) the emergence of a new meaning of an already existing lexeme (semantic derivation) - such changes apply directly to the semantics of language. The latter case causes the phenomena of polysemy and homonymy and is a manifestation of semantic divergence or semantic variability.

2. Intrinsic (Intra-lingual) causes. The bases of these causes are merely linguistic factors. Such phenomena develop within the language and are predetermined by the needs of its development; they are embedded in the language itself, in its internal system, in its capabilities and tendencies. M.P. Kochergan describes these factors as "contradictions within language, the struggle between which causes a change". He explains that "... all such contradictions are reduced to contradictions between the needs of communication and linguistic capabilities" $"$. For example, we may frequently observe in the language tendencies towards economy, unification, linguistic systematicity, influence of context, pragmatic purposes, expressive and emotional evaluation and stylistic colour, etc.

Extra- and intra-lingual causes of semantic change are interrelated, and linguistic changes themselves are often the result of the interaction of external and internal factors. Semantic changes, as well as linguistic changes in general, take place at both the systemic (language level) and non-systemic (speech) levels. Considering the phenomenon of semantic change over time, we can conclude that the change is first realized in speech (oral or written) and has a sporadic, occasional character. If frequent use of lexical items in a new meaning is spread among speakers, then with the subsequent entry of such meaning into the language system, semantic change becomes regular and normative, i.e. the new meaning is fixed not only in the minds of the speakers, but also codified in dictionaries. For example, the use of the

${ }^{6}$ Кочерган М.П. Вступ до мовознавства : Підручник. Київ : Академія, 2014. С. 47; Кочерган М.П. Загальне мовознавство : Підручник. Київ : Академія, 2010. C. 343-349. 
diminutive casucha in the positive, affective sense is rather occasional. In the language system, the diminutive suffixal formant -ucho has a pejorative, derogatory meaning. The Dictionary of the Spanish Royal Academy records the following meanings: casucha - 1. casa pequeña y mal construida. 2. choza, cabaña. 3. casa en destrucción; casa abandonada ${ }^{7}$ The English equivalents of the Word might be shack, shanty, shovel, slum. However, in a certain context, the diminutive loses pejorative and disdainful connotations and is used as a diminutive word that in this context can be translated into English as hut, cabin, cottage. For example, in the story "May Flower" by Venezuelan writer Luis Manuel Urbaneja Achelpohl we find:

- El calor de la ciudad me mata. No quiero más que hacer una siesta tranquila en mi casucha.

- No sabía que vive por aquí, señora.

- ... en La Fundación.

- ... bueno, que es una hacienda ${ }^{8} \ldots$

The category of diminutiveness is not objective, since in this case the term casucha is a hut with an affective connotation; and the character calls her house a hut, which is actually a large estate - una hacienda. The development of the meaning is rather unpredictable as the simple diminutive derives a series of meanings like: 1) nightclub: Y mientras esperaban en la calle algún taxi que las sacara de esos tierrales, la música volvió a retumbar en la casucha de la Palma, volvieron los tiritones y el mambo número ocho dio inicio al show; 2) hennery: La obra que iniciamos en la casucha de pollos ha crecido mediante el arduo trabajo y las bendiciones del Señor; 3) drug den: La escena es mucho más perversa, a los ricos pibes les entretiene parrandear en la casucha, donde se aglutinan en un recinto pequeño para tomar birras y drogarse; 4) disorderly house: La amante del dueño de la casucha responde frente al asedio de las mujeres burguesas y sus preguntas sobre las visitas tardías de sus maridos ${ }^{9}$.

Contextual use of the word allows for various semantic modifications. The meaning of a word in a particular speech does not necessarily

\footnotetext{
${ }^{7}$ Here and further on the meanings of the Spanish words cited as examples are given on the basis of the following dictionaries: 1) Diccionario de la Lengua Española. Madrid : Real Academia Española, Vigésima tercera edición, 2014. T. I a/g. P. 1-1180; T. II h/z. P. 1181-2369; 2) Испанско-русский словарь / Под редакцией Б.П. Нарумова. Москва, 1988; 3) Испанско-русский словарь. Латинская Америка / Под редакцией H.М. Фирсовой. Москва, 2004; 4) Merriam-Webster's Spanish-English Dictionary. Newest Edition, 2016; 5) Diccionario Básico de Español Larousse. URL: https://www.larousse.mx/app/diccionario (дата звернення: 29.04.2020).

${ }^{8}$ Urbaneja Achelpohl L.M.. Flor de Mayo. La Casa de las Cuatro Pencas. Tipografia Americana, 2007.

${ }^{9}$ Corpus del Español, Web Dialectos. URL: https://www.corpusdelespanol.org/web$\mathrm{dial} /$ (дата звернення: 25.04.2020).
} 
correspond to the normative, generally accepted, and known to all speakers meaning that is reflected in lexicographic sources. Diminutives and augmentatives, as lexical and semantic units are prone to connotation and expressiveness and are often a means for the speaker to express his or her own judgment. And it is the communication situation, the context, the background information, the pragmatic intentions of the speaker, etc. that determine the semantics of the diminutive or the augmentative.

\section{The category of meaning of diminutives and augmentatives}

The complex semantic nature of diminutives and augmentatives enhances studying the relationship between the meaning of the derivative (respectively, diminutive or augmentative) and the basic word. In this aspect, it is worth defining the concept of formative meaning of lexical items. Linguists distinguish three types of word meaning: lexical meaning, grammatical meaning, and formative (also known as word-forming or derivative) meaning ${ }^{10}$. In modern semiology, the concept of the wordforming (derivative) meaning is rather controversial.

There are many points of view among linguists as to the appropriateness and legitimacy of allocating word-forming meaning to a particular type. For example, some scholars consider derivative meaning to be a kind of lexical, or a kind of grammatical meaning. Other researchers have identified derivative meaning as a separate kind of meaning, different from lexical and grammatical, but at the same time closely related to them.

The most common approach states that the formative meaning is expressed and reflected in the derivative word ${ }^{11,12,13}$. The derivative word is a secondary lexical formation, which is closely related to the original generating unit. In the most general cases, the formative meaning is explained as a relationship between the meanings of the original and generated (derivative) words. Such an interpretation views the idea of formative meaning as a reference to an object, a process or an attribute by means of and through another object, process or attribute ${ }^{14}$. For example, the term apagador (switch) reflects the relation of the subject to the action; the adjective férreo (iron) refers to the relation of the attribute to the object; and

${ }^{10}$ Алефиренко Н.Ф. Спорные проблемы семантики : Монография. Москва, 2005. C. 225 .

${ }^{11}$ Кубрякова Е.С. Типы языковых значений: Семантика производного слова. Москва : Наука, 1981. С. 5.

12 Ермакова О.П. Проблемы лексической семантики производных и членимых слов : автореф. дис. ... докт. филол. наук : 10.02.04. Москва, 1977. С. 10.

${ }^{13}$ Улуханов И.С. Словообразовательная семантика в русском языке и принципы ёё описания. Москва : Книжный дом ЛИБРОКОМ, 2012. С. 77.

${ }_{14}$ Кубрякова Е.С. Типы языковых значений: Семантика производного слова. Москва : Наука, 1981. С. 11. 
the diminutive negrillo (field elm, botanical term internationally known as ulmus minor) points to the relation of the object to the attribute. Thus, the special feature of the meaning of the derived word is that the derivative meaning is manifested through the meaning of the original, primary sign, by pointing to an already existing name in the language that is considered to be motivational. In the above examples, a direct correlation of the derivative meaning with the deriving one can be traced: apagador < apagar; férreo < ferro, hierro; negro < negrillo.

Thus we can conclude that all derivative words are motivated and that the meaning of the diminutive / augmentative expresses: 1) relations existing between the diminutive / augmentative unit and its corresponding generator equivalent; 2) relations existing between the diminutive / augmentative and the speaker that are manifested directly in the context of the speech act.

That is why in the process of defining the word-forming meaning of diminutives and augmentatives, it is necessary to establish: 1) the direction of the word-forming origin; 2) the semantic relationship between the motivating and the motivated units; 3 ) the contextual characteristics of speech and pragmatic intentions of speakers since the two determine the connotation component of meaning of derivatives.

The connection of the derived word and the marked object is determined not only by the basic, motivating meaning, but also by the semantic value of the word-building formant (in our case, the diminutive or augmentative suffix).

Different derivative terms, formed by means of one diminutive or augmentative suffix have the common connotation of diminution or augmentation respectively. That is, the word-forming meaning of the words formed according to one derivative model is common. According to E.S. Kubryakova, the part of the derivative word that repeats the categorical and lexical meanings of the motivating unit is named the reference part. It is contrasted by the formative part, that is, the one that forms the new meaning of the derivative word ${ }^{15}$. The formative part expresses both the form of change in the motivational lexical item and the newly created meaning.

The above mentioned principle is clearly revealed in the process of diminutives and augmentatives developing terminological meanings. For example: campana - 1) chime, bell; 2) cowl, lid (technical term). Its derived diminutives modify the meaning of the basic word in the following way: campanilla - 1) bell (technical term); 2) bluebell, bellflower, campanula (botanical term); 3) garden daffodil (botanical term); 4) uvula (anatomy term); 5) little tassel for ladies' gowns (sewing term); 6) cabin-bell (nautical

15 Кубрякова Е.С. Типы языковых значений: Семантика производного слова. Москва : Наука, 1981. С. 14. 
term); 7) electric bell (technical bell, Argentinian and Mexican Spanish); 8) a variety of liana (botanical term, Cuban Spanish). Interestingly, the collocation de campanilla or de muchas campanillas means "of importance or consideration". Yet the gender correlate campanillo narrows the meaning of the derivative and stands for "cattle bell made from metal" (Argentinian Spanish). The diminutives formed with suffixes -ito and -uelo also retain a semantic link to the motivating word: campanita - cowl, lid (technical term); campañuela - lampshade (Venezuelan Spanish).

In this case, the change of meaning is due to metaphorical transfer. In all the examples cited above, the seme of the motivational word "bell" remains unifying. It is the bearer of cognitive associations with the form (cap-shaped object) and function (object that produces ring-like sounds) and determines the meaning of the derived word. The formative part (the diminutive suffix) causes a change in the meaning of the underlying lexical item, which results in polysemy and semantic variability. Such multifaceted modification of meaning raises the question of the role of the basic word and the formant part (the suffix) in the formation of the semantics of the derivative word.

The specific features of diminutives and augmentatives is the fact that, depending on the pragmatic situation, their meaning is contextually prone to semantic transformations, which makes the connection with the motivating word not always obvious. First and foremost, this applies to diminutives and similarly augmentatives that have undergone a process of being converted into terms and are an integral part of the scientific style of the Spanish language. The above does not in any way deny the generally accepted view of the motive of word-making in linguistics, but is only a necessary remark in the context of the study of the semantics of diminutives and augmentatives in Peninsular and Latin American national variants of the Spanish language.

E. Vúcheva points out that in terms of lexical structure, diminutives and augmentatives belong to the class of secondary paradigmatic structures ${ }^{16}$. By calling these derivatives paradigmatic structures, they imply that they are in opposition within the word-forming line, for example: coche-cochecitocochazo, casa-casita-caserón. At the same time, by denominating them secondary structures, it is noted that in these formations the basic or primary unit can be clearly distinguished. Indeed, the meaning of cochecito and cochazo or casita and caserón is determined by the semantic value of the primary forms coche or casa respectively, which is necessarily present in the content plan of the secondary units. However, the meaning of the derivatives

\footnotetext{
${ }^{16}$ Vúcheva E. Semántica y estilística de los diminutivos y los aumentativos. Foreign Language Teaching. No. 4. Sofia, 1999. P. 3-13.
} 
cochecito and cochazo or casita and caserón is not completely identical to the value of the primary forms of the lexic items coche or casa.

We should also note that secondary formations can be interpreted as additional definitions of the primary element. In fact, the forms cochecito and cochazo are additional definitions of the lexical item coche: the two forms, in this case the diminutive and the augmentative, are the result of semantic modification, which causes a difference in meaning between the source lexical unit and the derived one. That is why we propose to consider diminutives and augmentatives as secondary entities, additional definitions of a particular lexical meaning, which retain that meaning and express it as altered, reduced or enlarged, with a positive or negative connotation.

The additional definitions of the basic lexical items are expressed by means of morphological tools, in the case of Spanish, by adding diminutive and augmentative suffixes to the word stem. In addition to the grammatical means of expressing diminutiveness or augmentation, there are also lexical means. For example, the diminutives perrito, niñito express almost the same as the adjectival attribute pequeño in the phrases un perro pequeño, un niño pequeño. Similarly, the augmentatives ojazo, mantillón mean the same as un ojo grande, una mantilla grande, with the lexical means of expressing magnification being the adjective grande.

Nevertheless, there is a difference between the suffixal diminution and the adjectival diminution, as correctly noted by E. Coseriu ${ }^{17}$. In the case of a diminutive reduction, the object is considered internally small, small in absolute terms, and in the case of adjective reduction, externally small, small in relation to other objects or in relation to the previous state of the same object, that is, the category of diminution is being acquired. Examples illustrating this difference Me compré un cochecito / Me compré un coche pequeño confirm the fact that the suffixal diminution does not imply comparison with another car, unlike the adjectival diminution, which includes such a comparison, for example, to an earlier owned car, to a car belonging to somebody else, or to an idea of the car one was looking to buy. Suffixal diminution belongs to a category that E. Coseriu names "linguistic reduction", since it does not really express small size.

Similar remarks may apply to augmentatives. Following the principles by E. Coseriu regarding the diminutives, it is possible to distinguish suffixal augmentation (absolute) and adjectival augmentation (relative), as one existing only in comparison with another object, ideas about the normal size of the object or the previous state of the same subject. For example, in Me compré un caserón the house is large according to the speaker's own ideas and in Me compré una casa grande the house is truly large in objective reality.

${ }^{17}$ Coseriu E. El hombre y su lenguaje. Madrid, 1977. 
The demarcation of a diminutive (suffixal) diminution or augmentative (suffixal) augmentation attained by morphological tools belonging to the sphere of word formation, and the adjectival diminution or augmentation attained by the addition of an adjective attribute, according to the size or appearance of the object, indicates that, except for the difference in form, there is a difference in meaning depending on what the speaker is willing to express about the objects' characteristics.

Semantic divergences are realized directly in speech and are a manifestation of the expressive potential of the Spanish language. Diminutive reduction and augmentative enlargement, unlike adjectival ones, are capable of expressing the subjective attitude of the speaker towards the object, whereby diminutives and augmentatives acquire the functions of expressiveness, affection or disdain, and lose stylistic neutrality.

When determining the difference between the subjective and objective aspects of the categories of diminutiveness (reduction) and augmentation (enlargement), it should be remembered that the realization of the meaning of diminutives and augmentatives occurs directly in speech and depends on the context, so that the meaning of these derivative lexical items may be different and even opposite. This indicates that the meaning of diminutives and augmentatives is not straightforward, one-dimensional, and predictable; it is formed as a result of the interaction of the basic meaning with the special features of context and situation. Therefore, we come to the conclusion that the specific meaning of the derivative is formed in the combination of semantics of three components:

1) the main component (the bearer of meaning of the primary lexical item), which is constant;

2) the component of meaning of the suffixal formant (the bearer of meaning of generalized diminution or augmentation), which is also constant in its nature;

3) the additional specifying component (a factor element) that circumstantiates and specifies the contextual meaning in a particular communicative situation and possesses a variable, dynamic nature.

\section{Types of semantic derivation of diminutives and augmentatives}

The triple nature of the semantic structure of diminutives and augmentatives is due to the complexity of their morphological structure and the presence of additional connotations in their implementation in speech. As derivative lexical items, these units combine the meanings of the basic word, the meaning of the word-forming element (the suffix), and the additional connotative values caused by the associative and cognitive connections between the signified and the primary meaning. Thus, we can 
conclude that diminutives and augmentatives possess a high degree capacity for semantic derivation and, as a result, for the development of polysemy.

This is of particular importance in the study of semantic derivation processes, especially terminologically related ones, since, according to our observations, subjective connotations, expressive appraisal, transference of similarity and contiguity are often the vehicle for the motivation of terms, despite their stylistic neutrality.

Diminutive suffixes have their own semantic meaning of diminution and affection, which is expressed in the derivative word. However, the nature of semantic modifications is complex, and often the formative suffixes lose the meaning of reduction in form or emotional attachment, endearment and affection, and contribute to the acquisition of a new meaning by the derived word. For example: hermano - brother, hermanito - little brother, dear brother, hermanillo - kind of ivy (botanical term, Costa Rican Spanish); hijo - son, hijito - little son, sonny, hijillo - rotten smell, stench (medical term, Guatemalan Spanish).

In Spanish, such a change in the meaning of a word leads to polysemy or homonymy within one national variant and to semantic variability and divergence at the level of the language system as a whole. The process of a lexical unit acquiring new meanings without changing its form is commonly called semantic derivation. Semantic derivation is defined as the formation of a derived meaning on the basis of the original one without any change of the linguistic $\operatorname{sign}^{18}$. The reasons for semantic changes are diverse and require detailed analysis. Semantic derivation occurs according to certain established models, like metaphorical, metonymic, hyponymic, and involves extension, narrowing, and various displacements of meanings, during which one object is transferred to another due to certain associations ${ }^{19}$.

According to our observations, the specific feature of semantic derivation is that it is often realized simultaneously with morphological derivation. That is, the semantic relation is established not within one word, but between two words related to certain word-forming relations. This phenomenon is characteristic of diminutives and augmentatives especially when these derivatives are undergoing the process of terminologisation. For example, in Spanish from the verb pisar - 1) (to) step; 2) to press with feet; to tread, to squeeze - a series of nouns is formed, many of them being terms of oenology: pisada, pisadera, pisador, pisadura, pisante. At the same time, the meaning of the derivative pisadera - a rug, a piece of carpet (Peruvian national variant) - comes from the first given meaning of the verb pisar - to step. The above mentioned examples trace the relationship between the

${ }^{18}$ Никитин М.В. Курс лингвистической семантики. Санкт-Петербург, 2007.

${ }^{19}$ Никитин М.В. Основы лингвистической теории значения. Москва, 2018. 
meaning of the basic word and the derived lexical item, all of them being part of the terminology of winemaking, while the derivative meaning "rug" derived from the basic unit "to step" retains neutral non-terminological value.

The noun piso is formed from the verb pisar and on the basis of the primary form's first meaning of "onset", "tugging", "extrusion" it derives the following values: 1) floor; 2); storey, level; 3) an apartment occupying the whole floor; 4) flat, apartment. Such variability of meanings indicates the internal tendency of the lexical item to semantic derivation. The use of the word piso in various fields of science and technology contributes to its terminologisation.

Thus, in military terminology and astronautics, piso is used to denote the stage or step of a rocket, while in mining it has the meaning "level, layer" and in printing it denotes a "block mount". Derivative formations from piso in general standard Spanish have only the usual meaning of diminutiveness (conceptual or stylistic, depending on the context), but in Latin American national variants its derivatives acquire not just a connotative meaning, but have a separate denotative one.

For example, in Peru and Chile, pisito means "carpet" and in Venezuela it denotes a "special cell in the monastery for receiving visitors"; in the shoe making terminology of the Mexican national variant, the diminutive pisillo has the meaning "sole of the shoe (usually not leather)". The augmentative pisón in the Iberian national variant denotes a device for ramming the surface, and in Argentina, Uruguay and Paraguay it has two meanings 1) mortar (the common Spanish term is mortero); 2) a mortar handle (the common Spanish term mango del mortero). The latter example illustrates a case of narrowing of the value due to metonymic transfer. The Pan-American meaning of the augmentative pisón - trampling, retains a direct connection with the generating unit piso < pisar and is synonymous with pisotón < pisotear - to trample.

In view of the above, in the course of the study of semantic derivation of diminutives and augmentatives it is necessary to distinguish the level at which semantic modifications occur.

\subsection{Semantic derivation at the level of a basic word and its derivatives}

If semantic derivation takes place at two levels, i.e., at the level "basic word - derivative", due to the incorporation of the corresponding wordformant to the base lexical items, a new lexical unit is formed, which has a new meaning (meaning 2), different from the value of the original word (meaning 1). The meaning of the basic unit is determinative and undergoes semantic modification under the influence of the suffixal formant. The meaning of the derivative depends on the meaning of the original item, which is the motivating unit, but the role of the semantics of the suffix is 
decisive in forming the meaning of the newly formed word. As a rule, the diminutive suffixes, joining the base, give the derivative the meaning of diminution. For example: perro - perrito, perrillo, perrico, perrín. However, the category of diminution not only implies a sign of "small size" but also includes attributes of endearment. Therefore, diminutives are a means of expressing a kind, affectionate, or overly emotional, positive attitude of the speaker towards an object that is labelled as a diminutive. In this case, the derivative series mentioned above as an example, "dog - doggy / little dog" is used to refer not only to a small dog or a puppy or a dog that is young in age, but it is a means of affectionate pet treatment. The realization of the component of affection depends on the specific conditions of speech, the situation, the communicative intention, the relevant context, the pragmatic background and so on. It is worth noting that certain diminutive suffixes include semantic tokens of pejorativeness, depreciation, abjection or disdain and even irony, for example: perro - perrucho, miga - migaja, médico medicucho (Venezuela), amigo - amiguete (Peru).

In addition to providing diminutive, affective, or descriptive values, suffixal diminutive morphemes can modify the meaning of the basic word by secondary nomination, when the derivative value loses direct relation to the motivating value and the derivative moves to another lexical and semantic field. In Spanish this phenomenon often occurs as a result of metaphorical and metonymical transfer.

For example: common Spanish terms gato - 1) cat (zoological term); 2) jack (technical term); gatillo -1) dental forceps (medical term); 2) trigger (military and weaponry term); 3) withers (zoological term) and Chilean term gatillo - crista, long mane of a horse (of a certain breed). Semantic divergences are also manifested in the diminutive formations of terms derived from the word perro - dog: perrito - M. 1). prairie dog (rodent) (zoological term); 2) sweet pea (botanic term); perrillo - 1) gate valve, sluice valve (technical term); 2) trigger (technical term); 3) variety of a long machete (agricultural term, Puerto Rican Spanish); perrilla - sty, inflammation of a gland of the eyelid (eye disease) (medical term, Mexican Spanish); perreta - anger attack, rage, obsession (medical term, Cuban, Chilean Spanish).

A similar phenomenon applies to augmentatives. Suffixes expressing the idea of magnification, when joined to a base word, can give it the meaning of: augmentation: cubo - cubote, gamella - gamellón; pejorative and despective connotations: libro - libraco, amigo - amigacho, amigazo; affection, endearment: guapo - guapetón; modify the meaning of the element formed: the basic lexical item cubil - 1) lair, den (zoological term); 2) channel, riverbed, streambed, waterway (geographical, hydrographical term); the augmentative cubilote - coal furnace, shaft furnace (technological 
term), and cubilete - 1) baking form (culinary term); 2) meatloaf (baked in a special form) (culinary term); 3) a glass or a box for dice usually used by magicians (entertainment industry term); 4) cylinder hat (fashion term common in Latin American Spanish); 5) intrigue, fraud (used in Peru, Chile and Rio de La Plata area).

The semantic derivation analysed above is considered in terms of the relation between the form and meaning of the derivative lexical item and the form and of the underlying or basic lexical item. The approach we have proposed includes an analysis of the meanings of the original word and its diminutive, and augmentative derivatives, which can be a common or special term and refer both to the field of common Spanish vocabulary and to the vocabulary of several or one Latin American national variants.

\subsection{Semantic derivation of derivatives of a basic word}

If semantic derivation takes place at the "derivative only" level, the motivational word is not interpreted as a source of semantic variability, and its influence on the semantics of the derivative of the lexical item is not considered. This approach is based on the idea that the phenomenon of semantic derivation can occur at the level of the derivative of the lexical unit, that is, within the diminutive or augmentative formation. Therefore, it is polysemy we are dealing with, that is the presence of different lexical meanings in the same word according to different contexts. In this case, the derivative word (diminutive or augmentative) is multivalent and polysemous, and each of its meanings is considered in relation to the previous ones, regardless of the meanings of the original word.

For example: casita - 1) small house; 2) toilet; dressing room (Chilean Spanish); caseta - 1) one-storeyed house; 2) stall, booth, kiosk; 3) bathing hut, changing room, cabin (on the beach); 4)kennel, doghouse; casilla 1) watchman cabin, guard booth, guardhouse, keeper's lodge; 2) theatre box office; 3) trade tent; tray; 4) trap for catching birds (Cuban Spanish); 5) street lavatory room (Ecuadorian Spanish); 6) cabin (on the beach) (Argentinian Spanish); 7) everyday goods store (Mexican Spanish); 8) voting station, polling station (South American Spanish); 9) railway car (Latin American Spanish). The pejorative value is manifested in the diminutive casucha - 1) hut; poor house; 2) a ruined abandoned house. Augmentatives casona - 1) a large house; a backhand house; an uglylooking house 2) an old family estate (used mostly in the province of Santander, Spain); casote - 1) a large house; 2) skyscraper (colloquialism, Venezuelan Spanish); caserón - large clumsy house, house - are also examples of semantic derivation of single-stem derivatives of lexical items. The examples above illustrate various directions for meaning changing of a derivative word, with the common feature being the seme "small space 
limited in space" for diminutives and "big, large, enormous" for augmentatives.

Based on the morphological and semantic analysis above, we propose a classification of types of semantic derivation of diminutives and augmentatives, which underlies the level of implementation of semantic change:

1. External or word-forming (derivative) semantic derivation comprises modifications of the meaning of the basic lexeme as a result of its transformation by means of a diminutive or augmentative suffixal formant, that is, the derivative word acquires a new meaning different from the meaning of the original word. This type of semantic derivation has a vertical, paradigmatic character. Since the direction of change of meaning originates from the generative lexical item to the formed one, we suggest to call such semantic derivation extra-lexical, indicating that it takes place outside of one word and occurs on two levels.

2. Internal semantic derivation presupposes modifications of the primary meaning of the derivative word, the development of polysemy of the derivative due to various internal and external linguistic factors. This type of semantic derivation is linear. Since the direction of change of meaning occurs within a single lexical item (in our case, a diminutive or an augmentative), let us call such a semantic derivation intra-lexical, since it takes place within one word and occurs at the only one level.

\section{CONCLUSIONS}

Diminutives and augmentatives, as derived lexical units, develop intrinsic meanings of their own other than the meaning original lexical item. The meaning of diminutives and augmentatives includes three generalized components: the principal component (the bearer of the meaning of the basic lexical item), which is constant; a component of the value of the suffixal formant (the bearer of the generalized meaning of diminution or augmentation), which is also permanent; and an additional component (specifying contextual meaning in a particular communicative situation) that has a variable, dynamic nature. The triple nature of the semantic structure of diminutives and augmentatives is due to the complexity of their morphological structure and the presence of additional connotations in their implementation in speech, caused by the associative and cognitive connections between the secondary and the primary meaning.

The complexity in the structure of the values of diminutives and augmentatives determines the high degree of proneness of these derivatives to semantic derivation, and, as a result, to the development of polysemy. Semantic derivation of diminutives and augmentatives can occur at two levels: internal (acquiring new meanings by the original or the derivative 
word) and external (changing meanings from the generating (basic, original, primary) unit to the generated (derivative, originated, secondary) one).

The outlined types of semantic derivation are of practical importance in choosing the approach in the study of the semantics of diminutive and augmentative formations. However, diminutives and augmentatives are derivative words; the presence of a diminutive (augmentative) as a separate lexical item, with its own meaning, or several meanings, functional, stylistic and pragmatic scopes, context of implementation and other characteristics, implies that there is a source of this diminutive (augmentative), a basic lexical item, which also has relevant attributes and characteristics, including meanings. Therefore, the proposed classification is the determinant of the starting point in the analysis of forms of semantic derivation: should we take into account the original word or consider variability in the meanings of its derivatives. The lexical and derivative features of diminutives and augmentatives require a dual approach to study their semantics and semantic divergences, as the case may be. Besides, when taking into account the variety of suffixal formants, which directly contributes to a variety of forms and meanings, it is promising to further study the semantic derivation of diminutives and augmentatives in standard Spanish and its national variants.

\section{SUMMARY}

The article deals with the problems of meaning of diminutives and augmentatives in modern Spanish. The complex morphological and semantic characteristics of diminutives and augmentatives in the Spanish language contributes to a study of the relationship between the derivative (respectively, diminutive or augmentative) and the basic word. The tendency of diminutive and augmentative formations to semantic derivation, that is acquisition of new values without changing the form of the sign, and their frequent use in both informal and formal speech, including scientific and technical contexts, lead to the study of the mechanisms of formation of new conceptual meanings of these derivatives. The semantic derivation of diminutives and augmentatives is considered in the present paper in close connection with the morphological derivation, since the nature of the meaning of the derived word is directly dependent on the semantic features of the original word. Therefore the article aims to describe the category of meaning of diminutives and augmentatives, to analyse the types of semantic change and to propose a classification of semantic derivation. Such a classification of models of semantic derivation takes into account the level of semantic modifications, depending on whether the change of meaning takes place only within the derivative or the meaning of the derivative is determined by the semantic features of the primary lexical item. 


\section{REFERENCES}

1. Степанов Г.В. Социально-географическая дифференциация испанского языка Америки на уровне национальных вариантов. Вопросы сочиальной лингвистики. Ленинград, 1969. С. 302-305.

2. Шмелев Д.Н. Проблемы семантического анализа лексики. Москва, 1973.

3. Kany Ch.E. American Spanish Semantics. The University of California Press, 1960. 295 p.

4. Kany Ch.E. Semántica hispanoamericana. Madrid : Aguilar, 1962. 298 p.

5. Телия В.Н. Вторичная номинация и ее виды. Языковая номинация. Виды наименований. Москва : Наука, 1977. С. 129-221.

6. Левицкий В. Семасиология. Винница : Нова книга, 2012.

7. Кочерган М.П. Вступ до мовознавства : Підручник. Київ : Академія, 2014.

8. Кочерган М.П. Загальне мовознавство : Підручник. Київ : Академія, 2010.

9. Diccionario de la Lengua Española. Madrid: Real Academia Española, Vigésima tercera edición, 2014. T. I a/g. Pp. 1-1180; T. II h/z. Pp. 1181-2369.

10. Испанско-русский словарь / Под редакцией Б.П. Нарумова. Москва, 1988.

11. Испанско-русский словарь. Латинская Америка / Под редакцией Н.М. Фирсовой. Москва, 2004.

12. Merriam-Webster's Spanish-English Dictionary. Newest Edition, 2016.

13. Diccionario Básico de Español Larousse. URL: https://www.larousse.mx/app/diccionario (дата звернення: 29.04.2020).

14. Urbaneja Achelpohl L.M. Flor de Mayo. La Casa de las Cuatro Pencas. Tipografia Americana, 2007.

15. Corpus del Español, Web Dialectos. URL: https:// www.corpusdelespanol.org/web-dial/ (дата звернення: 25.04.2020).

16. Алефиренко Н.Ф. Спорные проблемы семантики : Монография. Москва, 2005.

17. Кубрякова Е.С. Типы языковых значений: Семантика производного слова. Москва : Наука, 1981.

18. Ермакова О.П. Проблемы лексической семантики производных и членимых слов : автореф. дис. ... докт. филол. наук : 10.02.04. Москва, 1977.

19. Улуханов И.С. Словообразовательная семантика в русском языке и принципы ёё описания. Москва : Книжный дом ЛИБРОКОМ, 2012. 
20. Vúcheva E. Semántica y estilística de los diminutivos y los aumentativos. Foreign Language Teaching. No. 4. Sofia, 1999. P. 3-13.

21. Coseriu E. El hombre y su lenguaje. Madrid, 1977.

22. Никитин М.В. Курс лингвистической семантики. СанктПетербург, 2007.

23. Никитин М.В. Основы лингвистической теории значения. Москва, 2018.

Information about the author: Stepanov A. V., Senior Teacher at the Department of Foreign Languages

Lviv University of Trade and Economics 10, Tuhan-Baranovskoho str., Lviv, 79005, Ukraine 